\title{
Study of Sales Forecasting Accuracy using ARIMA Model
}

\author{
Sunny Mathew ${ }^{1}$ and Ram Krishnan S. ${ }^{2}$ \\ ${ }^{1}$ Student (MBA), UIM Poojappura, ICM Campus, Thiruvananthapuram, Kerala, India. \\ ${ }^{2}$ Assistant Professor, MBA Department, Institute of Cooperative Management, Thiruvananthapuram, \\ Kerala, India.
}

CITATION: Mathew, Sunny and Krishnan, S. Ram (2020), "Study of Sales Forecasting Accuracy using Arima Model", MERC Global's International Journal of Management, Vol. 8, Issue 2, pp. 4046.

ARTICLE HISTORY: Submitted: November 29, 2019, Revision received: December 29, 2019, Accepted: January 29, 2020

ARTICLE TYPE: Research paper

\begin{abstract}
Forecasting is the program of action that entails an objective study of the past, present and future, to best estimate what that future holds in the way of sales for any given product or firm. One of the earliest recorded attempts at quantitative forecasting was that of John H. Patterson for the National Cash Register Company in 1887. Forecasting models have been widely investigated by researchers and practitioners. Here to understand the accuracy of forecasting, a study was conducted at Tata Global Beverages Limited (TGBL). The sample size for the study consists of the sales for the tea brand of TGBL during the last five years (April 2013 - March 2018). Holt Linear Trend, Holt Winter Model and Auto-Regressive Integrated Moving Average (ARIMA) model were used for forecasting the 2019 year sales data. Mean Absolute Deviation (MAD), Mean Squared Error (MSE), Root Mean Squared Error (RMSE) and Mean Absolute Percentage Error (MAPE) were used for finding accuracy and bar graphs are used for interpreting the results. The output of the study points out the variation between the forecasted sales and actual sales resulting in finding out the accuracy of a different model.
\end{abstract}

KEYWORDS: ARIMA, Forecasting, Sales, Forecasting models, Forecasting accuracy.

\section{BIBLIOGRAPHY}

1. Abraham, B. and Ledolter, J. (1983), Statistical methods for forecasting, John Wiley and Sons, New York.

2. Abraham, B. and Ledolter, J. (1986), "Forecast functions implied by autoregressive integrated moving average models and other related forecast procedures", International Statistical Review, Vol. 54, pp. 5166.

3. Archibald, B. C. (1990), "Parameter space of the Holt-Winters model," International Journal of Forecasting, Vol. 6, pp. 199-209.

4. Armstrong, J. S. and Fildes, R. (1995), "On the selection of error measures for comparison among forecasting methods," Journal of Forecasting, Vol. 14, pp. 67-71.

5. Brown, Robert G. (1950), Department of History \& Science, Harvard University.

6. Copeland, Melvin T. (1917), Business Statistics, Harvard Business Studies.

7. Davenport, H.F. (1912), "Heredity, Culpability, Praiseworthiness, Punishment, and Reward", Popular Science Monthly, July, pp. 35.

8. Diemer, Hugo (1921), Good place to work.

9. Holt, Charles C. (1957), Forecasting Trends and Seasonals by Exponentially Weighted Averages, Carnegie Institute of Technology, Pittsburgh Office of Naval Research.

10. Ingham, John N. (1983), "Clews, Henry: 'Biographical Dictionary of American Business Leaders", Volume 1, Greenwood Publishing Group.

11. Makridakis, S. and Wheelwright, S. C. (1989), Forecasting Methods for Management, John Wiley \& Sons, New York.

12. Patterson, John H (1923a), Pioneer in Industrial Welfare, Page \& Co., New York. 
13. Patterson, John H (1923b), The Romance of Business, Goffrey Bles, London.

14. Syntetos, A. A.; Boylan, J. E. and Disney, S. M. (2009), Forecasting for Inventory Planning: A 50-Year Review.

15. Tata Global Beverages Limited, Annual Budget Report 2016-2017.

16. Tata Global Beverages Limited, Annual Budget Report 2017-2018. 